\title{
直腸癌前方切除例の吻合法についての検討
}

一器械吻合と手縫い吻合との比較一

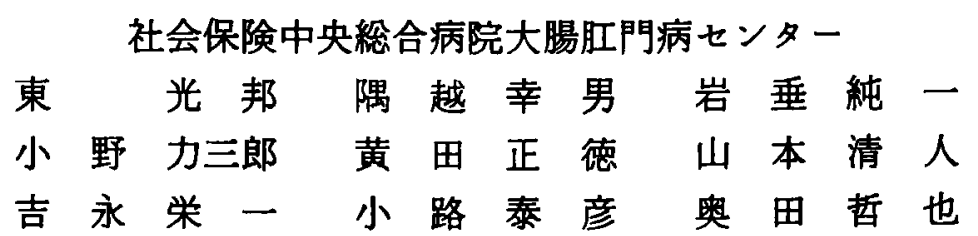

直腸癌に対する括約筋温存術式に於ける，器械吻合と手縫い吻合について比較検討を 行った。昭和44年から昭和63年まで，当センターで行った直腸癌前方切除例は212例であ り，そのらち手䋖い吻合は145例，器械吻合は67例であった，占居部位を比較すると，器

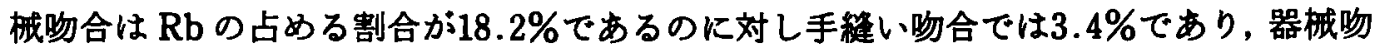
合では低位の吻合が多く，器械吻合は低位の吻合を可能にしたと考えられた，手術時間 を比較すると，手綎い吻合は平均196.1分であるのに対し，器械吻合では平均149.9分で あり器械吻合の方が短時間であった。術後早期の排便回数の比較では, 手絴い吻合，器 械吻合群の間に有意の差は認めなかった。術後早期の合併症を見ると器械吻合の方が少 なかった，局所再発率は器械吻合 $2.9 \%$ あるのに対し手縫い吻合 $3.9 \%$ と器械吻合の方 が低率であった．器械吻合は，安全で短時間に吻合することが可能である有用な術式と 考えられた。

索引用語：括約筋温存術式, 器械吻合, 手梿い吻合, 局所再発

\section{緒 吾}

近年，低位の直腸癌に対する括約筋温存術式の占め る割合は増加し，また手縫い吻合より器械吻合を行う ことが多くなってきている．図1に示すごとく，当科 に打いても直腸切断術に比べ前方切除術を行う場合が 多くなっている。そこでわれわれは手縫い吻合と器械 吻合を手術時間，術後排便回数，早期合併症，局所再 発率などの点から比較検討を行った。

\section{対象}

昭和44年から昭和63年まで当科で行った直腸癌の手 㭪症例数は795例であり,そのらちの括約筋温存術式で ある直腸癌前方切除例212例，（器械吻合67例，手絴い 吻合145例)を対象とした。 また，器械吻合の内訳は EEA 4 例, ILS 63例で，手䋖い吻合の内訳は Baker ${ }^{11}$ 法76例，Dixon"2)法69例であった。 また，両群の血管処 理, 吻合部位, リンパ節郭清に関しては一定の処理を 行ったものとした。即ち，血管処理は下腸間膜動脈根 部にて行い, Ra および $\mathrm{Rb}$ に位置する腫瘍の吻合法は
低位前方切除, Rsにおいては高位前方切除とし、リン パ節郭清に関しては $\mathrm{Rb}$ は側方リンバ節郭清を合わせ て行うことを原則とした。年龄は31歳から81歳まで平 均58.7歳であり, 手䋖い吻合群と器械吻合群とに分け て比較すると年龄及び性比に差を認めなかった，尚， 検定にはStudent's T, 及び $\chi^{2}$ 検定を用い, $\mathrm{p}<0.05$ を もって有意差ありとした。

\section{1) 手術時間}

図 2 に示すごとく，器械吻合は平均146.3土37.9分で

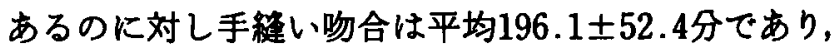
明らかに器械吻合の方が早かった。リンパ節郭清は吻 合法によらず同一に行っており，器械吻合によって手 術時間を短縮することができた。

\section{2) 術後早期の排便回数}

図 3 に示すごとく術後 3 週間の一日平均排便回数を 両群について比較してみると, 術後 1 週目は器械吻合 群平均 $1.0 \pm 1.6$ 回であるのに対し手䋖い吻合群では $1.08 \pm 1.53$ 回であり， 2 週目は器械吻合群 $3.61 \pm 1.66$ 回, 手縫い吻合群は3.88土1.78回, さらに 3 週目にな 


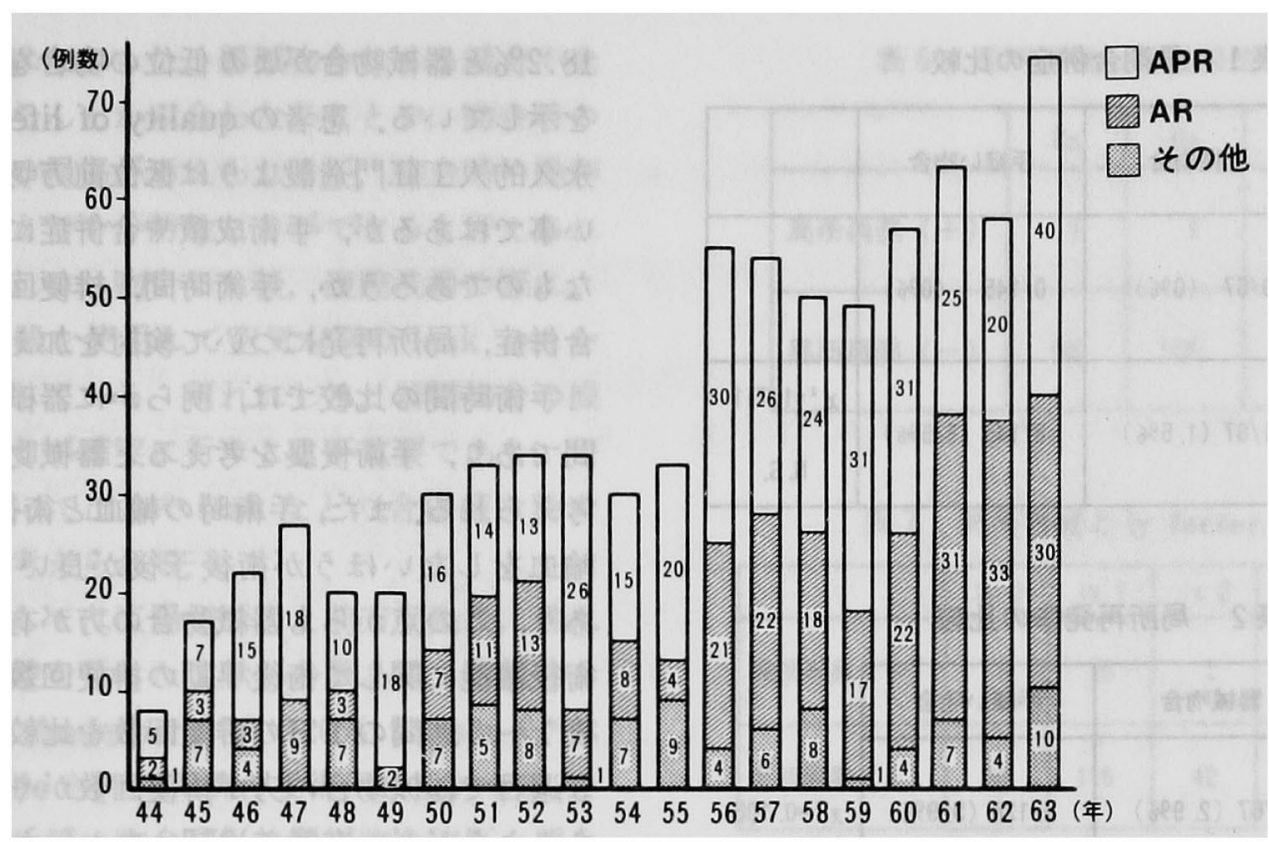

図 1 直腸癌手術に於ける術式の内訳

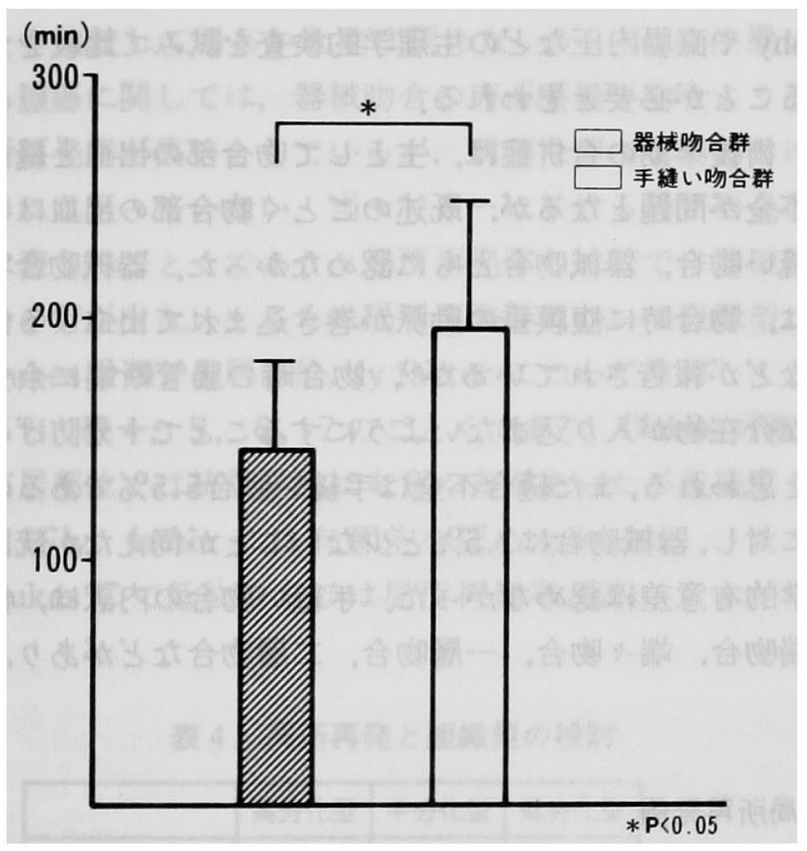

図 2 手術時間の比較

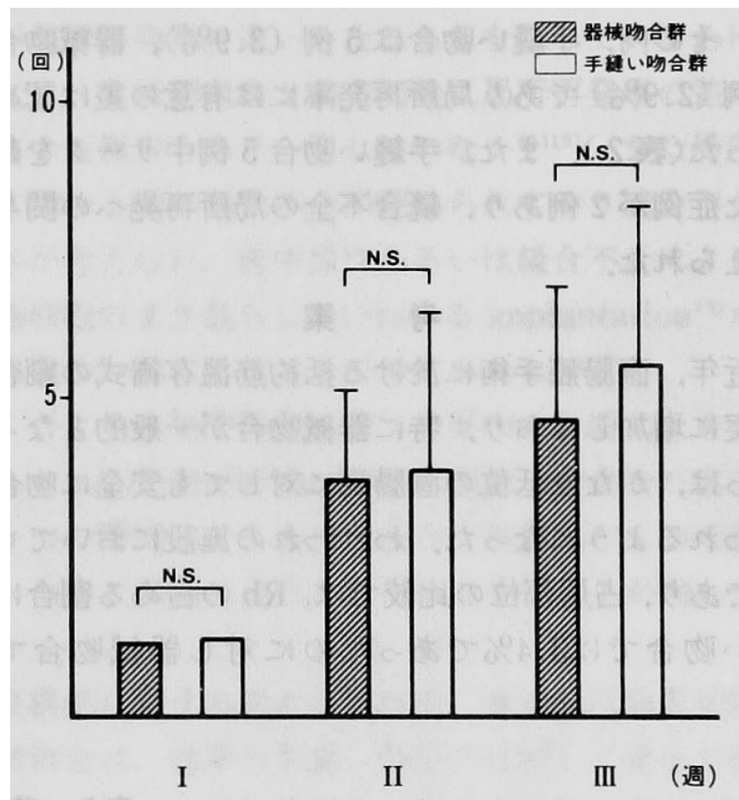

図 3 術後早期の排便回数の比較
ると器械吻合群4.56士2.20回，手释い吻合群5.40土 3.51 回と $2 \sim 3$ 週目には器械吻合群の方が排便回数の 减少が見られたが，両群に有意の差は認めなかった。

\section{3）早期合併症}

術後早期の合併症には吻合部出血, 縫合不全などが 挙げられるが，両群の吻合部出血と縫合不全について 比較した，出血例は手縫い及び器械吻合群とも 1 例む 認めなかった，表 1 に示すごとく，縫合不全は，手縫 い吻合では145例中 8 例 $(5.5 \%)$ に認められたのに対

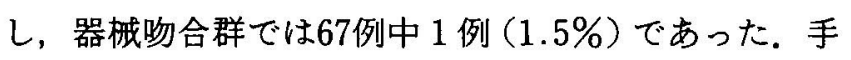
縫い吻合における吻合法の比較をしてみると，縫合不 全 8 例中 Albert-Lembert 法を用いた Baker 法 3 例, Dixon 法 3 例, Gambee一層吻合法 2 例であった。 器 械吻合の方が縫合不全は少ないことが同えたが統計学 的な有意差は認められなかった。

4) 局所再発

前方切除例212例中, 非治癒切除例17例を除き少なく とむ6 月月以上経過を観察した195例につき検討を加 えた。局所再発を起こした症例は 7 例 $(3.6 \%)$ であっ 
表 1 早期合併症の比較

\begin{tabular}{|c|c|c|c|}
\hline 合併症 & 器㖑吻合 & 手繾(吻合 & \\
\hline 物合部出血 & $0 / 67 \quad(0 \%)$ & $0 / 145 \quad(0 \%)$ & \\
\hline 䋖合不全 & $1 / 67(1.5 \%)$ & $8 / 145(5.5 \%)$ & $x^{2}=1.711$ \\
& & & N.S. \\
\hline
\end{tabular}

表 2 局所再発率の比較

\begin{tabular}{|c|c|c|}
\hline & 器械吻合 & 手維い吻合 \\
\hline 局所再発率 & $2 / 67(2.9 \%)$ & $5 / 128(3.9 \%)$ \\
\hline
\end{tabular}

た。 その内，手槰い吻合は 5 例 (3.9\%)，器械吻合は 2 例 (2.9\%) であり局所再発率には有意の差は認めな かった(表 2$)$ ）また，手縫い伆合 5 例中リークを起こ した症例が 2 例あり, 縫合不全の局所再発への関与が 考えられた。

\section{考案}

近年，直腸癌手術に於ける括約筋温存術式の割合は 確実に増加して打り，特に器械吻合が一般的となって からは，かなり低位の直腸癌に対しても安全に吻合が 行われるよらになった。われわれの施設においても同 様であり, 占居部位の比較では, $\mathrm{Rb}$ の占める割合は手 縫い吻合では3.4\%であったのに対し器械吻合では
$18.2 \%$ と器械吻合がより低位の吻合を可能にしたこと を示している. 患者の quality of life の点から言って 永久的人工肛門造設よりは低位前方切除の方が望まし い事ではあるが，手術成績や合併症に関してはどの様 なものであろうか, 手術時間, 排便回数, 術後早期の 合併症，局所再発について検討を加えた。

手術時間の比較では, 明らかに器械吻合の方が短時 間であり，手術侵撉を考えると器械吻合の方が有利と 考えられる。立た，手術時の輸血と術後予後に関して， 輸血をしないほらが訹後予後が良いとする報告3)4 も ありここの点からす器械吻合の方が有利と思われる。 術後機能に関して術後早期の排便回数から見ると, 術 後 1 ～ 3 週間の 1 日の排便回数を比較してみると, 2 , 3 週目で器械吻合の方が排便回数がやや少ない傾向に あるようだが，有意差は認めなかった，機能的には器 械吻合と手縫い吻合では差は認められない(5) と考えら れるが，さらに長期の排便回数を比較し， defecography や直腸内圧などの生理学的検査を試みて比較をす ることが必要と思われる。

術後早期の合併症は, 主として吻合部の出血と縫合 不全が問題となるが，既述のごとく吻合部の出血は手 繸い吻合，器械吻合ともに認めなかった。器械吻合で は，吻合時に腹膜垂の動脈が巻き込まれて出血する例 などが報告されているが6)，吻合時の腸管断端に余分 な介在物が入り込まない上らにすることで十分防げる と思われる。また縫合不全は手縫い吻合 $5.5 \%$ であるの に対し，器械吻合は $1.5 \%$ と少ないことが同えたが統計 学的有意差は認めなかった。手縫い吻合の内訳は，側 端吻合, 端々吻合, 一層吻合，二層吻合などがあり，

表 3 前方切除後の局所再発例

\begin{tabular}{|c|c|c|c|c|c|c|c|c|c|c|c|}
\hline 症 㑬 & 部位 & 吻合 & 大きさ & 深達度 & 型 & $n$ & $v$ & ly & AW & $\begin{array}{c}\text { Dukes } \\
\text { 分積 }\end{array}$ & \\
\hline 1 & $\mathbf{R a}$ & $\begin{array}{l}\text { 摔端 } \\
+ \text { 十. }\end{array}$ & $3.5 \times 3.0$ & $\mathbf{S}_{2}$ & 2 & 1 & 1 & 1 & $2 \mathrm{~cm}$ & c & \\
\hline 2 & Rab & 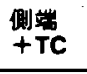 & $\begin{array}{r}4.0 \times 3.8 \\
\mathrm{~cm}\end{array}$ & $\mathbf{S}_{2}$ & 2 & 2 & 1 & 1 & $2 \mathrm{~cm}$ & B & \\
\hline 3 & Rs & 側踹 & $\begin{array}{r}3.5 \times 4.0 \\
\mathrm{~cm}\end{array}$ & $\mathbf{S}_{\mathrm{i}}$ & 3 & 1 & 2 & 2 & $3 \mathrm{~cm}$ & C & 敏合不全 (+) \\
\hline 4 & $\mathbf{R a}$ & $\begin{array}{l}\text { 端名 } \\
+\mathrm{TC} \\
\end{array}$ & $\begin{array}{r}5.0 \times 2.0 \\
\mathrm{~cm}\end{array}$ & $\mathbf{S}_{2}$ & 3 & 2 & 1 & 1 & $2 \mathrm{~cm}$ & C & 椹合不全 (t) \\
\hline 5 & $\mathbf{R b}$ & 端々 & $\begin{array}{r}4.0 \times 5.0 \\
\mathrm{~cm}\end{array}$ & $a_{1}$ & 2 & 1 & 1 & 1 & $2 \mathrm{~cm}$ & C & \\
\hline 6 & Rba & 器械 & $\begin{array}{r}3.5 \times 4.0 \\
\mathrm{~cm}\end{array}$ & $a_{1}$ & 2 & 1 & 1 & 1 & $3 \mathrm{~cm}$ & C & \\
\hline 7 & Rb & 器棫 & $\begin{array}{r}5.0 \times 6.0 \\
\mathrm{~cm}\end{array}$ & $a_{2}$ & 2 & 1 & 2 & 2 & $2 \mathrm{~cm}$ & C & \\
\hline
\end{tabular}

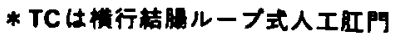


吻合法による差はなかった，器械吻合による縫合不全 は， stapleがきちんとかみ合わないことや，吻合時の 操作による粘膜の損傷が考えられるが, 吻合時の操作 を確実に行らことで十分防ぐことができると考兄られ る。またわれわれは，吻合した後，腹腔洗浄の際に， 肛門側より浣腸器を使用して空気を送り leak test 行い安全を確認している. 何れにしろ, 器械吻合の操 作は簡単ではあるが確実に行うことが重要であり，そ らすることによって出血や leakなどの合併症を防ぐ ことができると考えられる。

局所再発に関しては直腸切断術之前方切除術, 殊に 器械吻合との比較を行った文献が多数ある。器械吻合 の局所再発率は, Anderberg ら》は20\%, Lasson ら"は $35 \%$ とし, Neville ら"は373例の手術例に検討を加え， 直腸切断術 $19 \%$ 手縫い吻合 $17 \%$, 器械吻合 $24 \%$ 之明ら かに前方切除のらち器械吻合の方が局所再発率が高い としている。 また Rosen ら ${ }^{101}$ は手檤い吻合と器械吻合 とを比較して明らかな差は認めないが， Ra に位置す る畽陽に関しては, 器械吻合の方が手縫い吻合より局 所再発率が高いとしているが，明確な理由を結論付け るには至っていない，当センターに於ける局所再発群 は表 3 のごとくであり, 局所再発率の比較では器械吻 合の方が少ない．さらに局所再発群について組織型, Dukes 分類, 占居部位, ly factor について検討してみ ると，表 4，5，6，7 のごとくであり，Dukes 分類, 占居部位では統計学的に有意の差があったが組織型お よび ly factorには有意差を認めなかった。つまり Dukes Cで低位のものは局所再発率が高いことが伺

表 4 局所再発と組織型の検討

\begin{tabular}{|c|c|c|c|}
\hline & 高分化型 & 中分化型 & 低分化型 \\
\hline 局所再発 (+) & 5 & 2 & 0 \\
\hline 局所再発 (一) & 143 & 37 & 8 \\
\hline
\end{tabular}

表 5 局所再発と Dukes 分類の検討

\begin{tabular}{|l|c|c|c|}
\hline & Dukes A & Dukes B & Dukes C \\
\hline 局所再発 ( + ) & 0 & 0 & 7 \\
\hline 局所再発 (-) & 86 & 20 & 82 \\
\hline
\end{tabular}

表 6 局所再発と占居部位の検討

\begin{tabular}{|c|c|c|c|}
\hline & $\mathrm{Rs}$ & $\mathrm{Ra}$ & $\mathrm{Rb}$ \\
\hline 局所再発 (+) & 1 & 3 & 3 \\
\hline 局所再発 (-) & 53 & 126 & 18 \\
\hline
\end{tabular}

表 7 局所再発と ly factor の検討

\begin{tabular}{|l|c|c|c|c|}
\hline & Iy 0 & Iy 1 & ly 2 & ly 3 \\
\hline 局所再 (+) & 0 & 5 & 2 & 0 \\
\hline 局所再発 (-) & 30 & 115 & 42 & 1 \\
N. S. \\
\hline
\end{tabular}

えた。しかし、これは必ずしも吻合法の違い，術式の 差が局所再発率の違いとなることを示しているわけで はなく，直腸切断術之前方切除に局所再発率の差はな いとする報告もあり一定していない(1)12)。 また局所再 発 7 例中 2 例に縫合不全が認められており縫合不全の 関与が考えられ，術中操作あるいは縫合不全による遊 離癌細胞のまき散らし，いわゆる implantation ${ }^{13)}$ が局 所再発の一因となることが考えられた1415).

このように局所再発は種々の要因の影響によるるの であり, 肛門側切断端 (AW)の距離, 吻合法の違いな そーつの要因によるものではなく癌腫そのものの進行 度，つまり病期によるところが大きいことが伺えた。

\section{まとめ}

直腸癌に対する括約筫温存術, 殊に低位前方切除の 器械吻合は，従来の手檤い吻合に比較して安全で確実 に吻合が行え, 手術侵襲も少なくてすみ, 優れた吻合 法と考えられた。

術後合併症, 排便機能, 局所再発に関しても手縫い 吻合との差はなく，むしろ器械吻合の方が良好な結果 が得られた。低位の直腸癌に対しては器峨吻合は有効 な吻合法であると考えられた。

本論文の要旨は第50回日本臨床外科医学会総会（1988東 京), 及び第31回大腸癌研究会 (1989大阪) にて発表した。

\section{文献}

1) Baker JW: Low end to side rectosigmoidal anastomosis. Arch Surg $61: 143-157,1950$

2) Dixon CF : Anterior resection for carcinoma low in the sigmoid and the rectosigmoid. Sur- 
gery $15: 367-377,1944$

3）八木田旭邦, 竹内教能, 丽蓃 久：結腸癌と乳癌の 外科手術における輸血と予後, 日臨外医会誌 48 ： 185-191, 1987

4）小野寺久, 前谷俊三, 戸部隆吉：大腸癌患者の予後 に与光る輸血の影䇾の検討, 日外会誌 $90: 1890$ $-1898,1989$

5）浜野恭一, 亀岡信悟, 秋元 伸他：直腸癌の括約筋 温存術式, 臨外 $39: 1667-1673,1984$

6）松本政雄, 田村 潤, 森田恒治他：器械吻合による 前方切除後合併症の検討，日消外会誌 $18: 1304$, 1985

7) Anderberg B, Enblad P, Sjodahl R, et al: The EEA-stapling device in anterior resection for carcinoma of the rectum. Acta Chir Scand 149 : $99-103,1983$

8) Lasson AL, Ekelund GR, Lindstrom CG : Recurrence risk after stapled anastmosis for rectal carcinoma. Acta Chir Scand 150 : 85-89, 1984

9) Neville R, Fielding LP, Amenodola C: Local tumor reccurence after curative ressction for rectal cancer : A ten-hospital review. Dis Colon Rectum $30: 12-17,1987$

10) Rosen CB, Beart RW, Jr, Ilstrup DM : Local recurrence of rectal carcinoma after hand-sewn and stapled anastomosis. Dis Colon Rectum 28 : 305-309, 1985

11) Athlin L, Bengtsson NO, Stenling R: Local recurence and survival after radical resection of rectal carcinoma. Acta Chir Scand 154: 225 $-229,1988$

12）亀岡信悟：遠隔成績から見た直腸癌に対する前方 切除術の適応に関する研究. 日消外会誌 20 : 1938-1947, 1987

13) Goligher J : Surgery of the Anus Rectum and Colon. Fifth edition, Baellier Tindall, London, 1984, p454-456

14）隅越幸男：直腸癌に対する肛門機能温存術，外科 治療 $45: 79-86,1981$

15) Tomoda H, Furusawa $M$ : Local recurrence after curative anterior resection for carcinoma of rectum. Jpn J Surg $16: 377-379,1986$

\title{
A STUDY ON THE ANASTOMOSIS OF ANTERIOR RESECTION OF CARCINOMA OF THE RECTUM - COMPARISON OF THE STAPLED ANASTOMOSIS WITH THE HAND-SEWN ANASTOMOSIS-
}

\author{
Mitsukuni AZUMA, Yukio SUMIKOSHI, Jun-ichi IWADARE, Rikisaburo ONO, \\ Masanori KOUDA, Kiyoto YAMAMOTO, Eiichi YOSHINAGA, \\ Yasuhiko KOMICHI and Tetsuya OKUDA \\ Colo-Proctology Center, Social Insurance Central Hospital
}

Stapled and hand-sewn anastomoses were compared in the interest of preservation of the anal sphincter after anterior resection of cancer of the rectum. The number of anterior resection cases of rectal cancer treated at our clinical center from 1969 to 1988 was 212, and hand-sewn anastomosis was performed in 145 and stapled anastomoses, in 67 cases. When duration needed for these surgical procedures was compared, it was $196.1 \mathrm{~min}$ in an average in hand-sewn anastomoses, while $149.9 \mathrm{~min}$ in stapled anastomoses. There was no significant difference between the both procedures in the frequency of defecation in the early postoperative phase. As to complications in the early phase after operation, less complications were observed in stapled anastomosis cases. Local recurrence rate was $2.9 \%$ in stapled anastomosis and $3.9 \%$ in hand-sewn anastomosis cases. Thus, the stapled anastomosis is considered to be safe and clinically useful because it permits a shorter operation time with less complications. 